\title{
The relationship between measures of religiosity and the prevalence and outcome of COVID-19: a population-level pilot study
}

Ravi Philip Rajkumar ( $\sim$ ravi.psych@gmail.com )

Jawaharlal Institute of Postgraduate Medical Education and Research https://orcid.org/0000-00032699-7438

\section{Research Article}

Keywords: COVID-19, religiosity, prevalence, mortality

Posted Date: June 5th, 2020

DOI: https://doi.org/10.21203/rs.3.rs-33245/v1

License: (a) (i) This work is licensed under a Creative Commons Attribution 4.0 International License.

Read Full License 


\section{Abstract}

Religious belief and practice are associated with better mental and physical health as well as prosocial behaviour, both of which may influence the wide variations in prevalence and mortality due to the COVID19 pandemic observed to date. This study examined the association between measures of religious affiliation and practice and indices of the prevalence and mortality of COVID-19 across nations, and found evidence for a possible protective effect of religious belief and practice on the spread of COVID-19 as well as on mortality rates. This requires further investigation at a local and individual level.

\section{Introduction}

"He who dwells in the shelter of the Most High,

and abides in the shade of the Almighty, says to the LORD, 'My refuge, my stronghold, my God in whom I trust!'

He will free you from the snare of the fowler,

from the destructive plague..." (Psalm 91: 1-2)

The pandemic of acute respiratory illness (COVID-19) caused by a novel coronavirus (SARS-nCoV-2) has rapidly reached the proportions of a global health crisis, with over 5 million cases and 320,000 deaths reported to date (May 21, 2020) around the world. Besides its obvious impact on physical health, COVID19 has also been associated with a significant burden of psychological and socio-economic adversity, due to both the direct effects of the infection and the stringent measures necessary to curtail its spread (Pfefferbaum \& North, 2020; Rajkumar, 2020). In a sense, the COVID-19 outbreak can also be considered a spiritual crisis for believers in many countries, whose right to attend religious services and gatherings has been severely curtailed or abolished owing to the necessity of infection control measures, including lockdowns and quarantines (Quadri, 2020). An unexplained observation during this pandemic has been the wide variation in prevalence and mortality related to the disease, for which no simple explanation appears to be forthcoming (Al-Tawfiq et al., 2020).

Historically, religious belief and practice have provided comfort, material and spiritual support, and a sense of hope in the face of epidemics of infectious disease (Schupbach, 1976; Archambeau, 2011). More contemporary research has found robust evidence of a positive association between religion and spirituality and a variety of measures of physical and mental health (Koenig, 2012; Bonelli \& Koenig, 2013). Religiosity has also been associated with prosocial or altruistic behaviour, which is the tendency to behave in a way that benefits others even at a personal cost (Norenzayan \& Shariff, 2008). Such behaviour may be of direct relevance in mitigating the personal and social impact of disease outbreaks (Koenig, 2020).

Religion also plays an important role in fostering and maintaining hope in the face of disease and death (Van Ness \& Larson, 2002). Finally, all world religions include the practice of intercessory prayer or similar rituals in the face of illness, even though its efficacy in strictly scientific terms has been called into 
question (Roberts et al., 2009). None of these naturalistic findings should be seen as being in conflict with the transcendent purpose of religion; in the words of St Thomas Aquinas, "Gratia non tollit naturam, sed perficit" - grace does not destroy nature, but perfects it.

In the light of the above observations, the current study was carried out to examine the possibility of an association between indices of the prevalence and mortality related to COVID-19 and measures of religious affiliation and practice across nations.

\section{Methodology}

For the purposes of this study, all countries reporting at least 1000 cases of COVID-19, and for which complete information was available concerning both COVID-19 and religiosity, were included. National populations and COVID-19 - related statistics were retrieved using the estimates based on World Health Organization statistics and national reporting, as reported by the Johns Hopkins Coronavirus Resource Center (https://coronavirus.jhu.edu) and the Worldometers data aggregator (https://worldometers.info/coronavirus). Data regarding the following was captured on May 20, 2020: (a) crude prevalence, as measured by the number of cases per 1 million population, (b) crude mortality rate, as measured by the number of deaths due to COVID-19 per 1 million population, and (c) infection fatality rate, computed as the ratio of deaths to survivors among those patients for whom an outcome had been reported. Data on religious affiliation and practice across nations was obtained from the data published on June 13, 2018 by the Pew Research Center (Pew Research Center, 2018). This data set provided information on four relevant measures: (a) percentage of the population identifying as affiliated to a particular religion, (b) percentage attending religious services weekly, (c) percentage who pray daily, and (d) percentage who consider religion very important in their lives. General information on each nation's Human Development Index (HDI) was obtained from a relevant United Nations publication (United Nations Development Programme, 2019), as general socio-economic development was an independent factor that could influence disease spread and mortality. Complete data was available for a total of 73 countries meeting the above criterion, and all these countries were included in the final analysis.

All study variables were tested for normality. As neither the COVID-19 indices nor the measures of religiosity were normally distributed ( $p<0.01$ for all variables, Shapiro-Wilk test), Spearman's rank correlation coefficient $(\rho)$ was used to test for the presence of a monotonic association between them. All tests were two-tailed, and a value of $p<0.05$ was considered significant for the purpose of these exploratory analyses.

\section{Results}

The results of the correlation analysis are presented in Table 1. It can be seen that all four measures of religiosity at a national level - percentage reporting an affiliation, percentage attending services weekly, percentage praying daily, and percentage considering religion very important - were significantly and negatively correlated with both the prevalence of COVID-19, measured as cases per million population, 
and the crude mortality rate, measured as deaths per million population. However, none of these measures were significantly related to the infection fatality rate.

\section{Table 1: Correlations between COVID-19 indices and measures of religiosity ${ }^{\mathrm{a}}$}

\begin{tabular}{lllll|} 
& $\begin{array}{l}\text { Affiliated to a } \\
\text { particular } \\
\text { religion }\end{array}$ & $\begin{array}{l}\text { Attend religious } \\
\text { services every } \\
\text { week }\end{array}$ & $\begin{array}{l}\text { Pray } \\
\text { daily }\end{array}$ & $\begin{array}{l}\text { Consider religion } \\
\text { very important in } \\
\text { their lives }\end{array}$ \\
\hline $\begin{array}{l}\text { Prevalence, cases per } 1 \\
\text { million population }\end{array}$ & $-0.453^{\mathrm{b}}$ & $-0.460^{\mathrm{b}}$ & $-0.488^{\mathrm{b}}$ & $-0.482^{\mathrm{b}}$ \\
$\begin{array}{l}\text { Crude mortality rate, } \\
\text { deaths per 1 million }\end{array}$ & & & & \\
population & & & & \\
Infection fatality rate & & & & \\
\hline
\end{tabular}

$-0.494^{b}$
$-0.447^{b}$
$-0.478^{b}$
$-0.491^{b}$

$-0.116$
0.137
0.095
0.118

${ }^{\text {a }}$ All correlation coefficients represent Spearman's rho $(\rho)$ value

b Significant at $\mathrm{p}<0.001$.

It was also noted that all the four measures of religiosity were significantly and positively correlated with each other, with Spearman's $\rho$ ranging from 0.573 to 0.763 ( $p<0.001$, all correlations). Among the COVID19 indices, prevalence and crude mortality rate were positively correlated $(\rho=0.880, p<0.001)$, while crude mortality rate, but not prevalence, was positively correlated with the infection fatality rate $(\rho=$ $0.359, p=0.002$ ).

With regard to potential confounders, total population was significantly and negatively correlated with the prevalence of COVID-19 $(\rho=-0.328, p<0.005)$ and positively correlated with the infection fatality rate $(\rho=$ $0.275, p=0.018)$. Surprisingly, the HDI was positively correlated with the prevalence of COVID-19 ( $\rho=$ $0.628, p<0.001)$ as well as the crude mortality rate $(\rho=0.674, p<0.001)$. When the relationship between these variables and measures of religiosity was examined (Table 2), population was positively correlated 
with all measures except religious affiliation, while HDI was negatively correlated with all four measures. $\mathrm{HDI}$ and population were not significantly correlated with each other.

\section{Table 2: Correlations between COVID-19 indices and potential confounders ${ }^{a}$}

\begin{tabular}{|lllll} 
& $\begin{array}{l}\text { Affiliated to a } \\
\text { particular religion }\end{array}$ & $\begin{array}{l}\text { Attend religious } \\
\text { services every week }\end{array}$ & $\begin{array}{l}\text { Pray } \\
\text { daily }\end{array}$ & $\begin{array}{l}\text { Consider religion very } \\
\text { important in their lives }\end{array}$ \\
\hline Population & 0.142 & $0.356^{c}$ & $0.282^{\mathrm{d}}$ & $0.261^{\mathrm{d}}$ \\
\hline
\end{tabular}

Human Development $-0.742^{b}$ $-0.708^{b}$ $-0.786^{b}$ $-0.831^{b}$ Index (HDI)
${ }^{a}$ All correlation coefficients represent Spearman's rho $(\rho)$ value.
b Significant at $p<0.001$
${ }^{c}$ Significant at $p<0.01$
${ }^{d}$ Significant at $p<0.05$

When controlling for the effects of population, the negative correlation between all four measures of religiosity and prevalence remained significant ( $p<0.01$ for all partial correlations). However, when controlling for the effects of the HDI, the negative correlation between these measures was no longer significant ( $p>0.05$ for all partial correlations). An almost identical result was obtained for the crude mortality rate, where the association with indices of religiosity remained significant after controlling for population size ( $p<0.01$ for all partial correlations), but not after controlling for the HDI ( $p>0.05$ for all partial correlations).

\section{Discussion}

The above results provide some evidence for a protective effect of certain measures of religiosity, broadly defined at a national level, and both the prevalence and the crude mortality rates observed at this stage of the COVID-19 epidemic. This association remained strong when correcting for the effects of population size - which can influence both the above disease indices as it can cause a wide variation in the denomination - but not after correcting for the Human Development Index, which was itself negatively correlated with all measures of religious affiliation and practice. On the other hand, measures of religiosity had no apparent relationship with the infection fatality rate. 
These results may be interpreted in various ways. First, the protective effect of religiosity, if such an effect exists, may be chiefly exerted by its effects on disease prevalence and not on the outcome in infected patients. This may reflect the pro-social behaviours that are associated with religious affiliation and practice. Such behaviours could include a higher degree of compliance with infection control and hygienic measures, and a greater tendency to comply with the orders issued by local authorities. Such an effect may be particularly pronounced in low- and middle-income countries where religion is associated with a more collectivistic culture, particularly in the East (Cohen et al., 2016) and is consistent with epidemiological data from these regions. In contrast, no association was found between religiosity and case fatality, which seems to be more dependent on biological variables such as the presence of comorbid medical conditions or the levels of particular markers of inflammation and tissue damage (Du et al., 2020). The apparent effect on the mortality rate may simply reflect the fact this variable was strongly correlated with the prevalence of COVID-19, and behaviours that reduced the latter could significantly reduce the former.

Second, a potential effect of religious involvement on immunity cannot be ruled out. Religious involvement may be associated with enhanced immune function, which could potentially improve resistance to viral infections (Koenig, 2020). However, such an effect has not been directly demonstrated for infections with respiratory viruses such as SARS-nCoV-2.

Third, by fostering hope and providing a sense of purpose and of the transcendent (Cohen et al., 2016; Van Ness \& Larson, 2002), religious beliefs and practices could reduce the maladaptive emotional responses, such as fear and paranoia, that accompany disease outbreaks (Asmundson \& Taylor, 2020), and are often associated with maladaptive behaviours that may increase the risk of infection.

Fourth, religious beliefs in certain regions may go hand in hand with cultural practices, such as restrictions on social contact or dietary patterns, which might enhance immunity or minimize the risk of infection (Fincher et al., 2008). In such a scenario, any protective effect would arise from these customs rather than from religious beliefs themselves; however, these beliefs would imbue such customs with a sense of purpose and facilitate adherence to them.

Fifth, in view of the fact that the observed correlations were no longer significant when the effects of the HDI were taken into account, there may be underlying socio-economic or cultural factors that are responsible for the variations in prevalence and mortality, and that are incidentally related to religious belief and practice.

Sixth, the findings may simply reflect this study's methodology, particularly its cross-sectional nature. While the COVID-19 pandemic has already had a substantial impact in some countries, its course in others is still evolving, and it is likely that the estimates of prevalence and mortality used in this study will change over time. If this is the case, this could affect the significance and direction of any associations reported so far, particularly in low- and middle-income countries whose healthcare systems may be overwhelmed by increasing numbers of cases (Chiriboga et al., 2020). 
These results are subject to certain important limitations. First, data was obtained from aggregator websites and opinion polls, which are themselves subject to reporting bias and variability in the quality and accuracy of the information supplied. Second, the study is cross-sectional in nature and did not take into account the time course of the spread of COVID-19 across nations, or projections of possible future trends. Third, because of the non-normal distributions of all study variables, there was a limit on the power and precision of the statistical tests that could be carried out. Fourth, the measures of religiosity used in this study relate more to religious identity and practice than to its spiritual or transcendent dimension. Fifth, we have used "religiosity" as a unitary construct of sorts, whereas there is substantial variation in the beliefs, values and practices endorsed by different world religions in different geographical areas. Finally, there may be other confounding factors that have not been taken into account in this paper, such as demographic variations or variable rates of medical comorbidities across populations.

\section{Conclusion}

The results of this pilot study suggest that there may be a protective effect of religious affiliation and practice on certain aspects of the COVID-19 pandemic, specifically on its prevalence and crude mortality rate. This effect may be either direct, or due to social and cultural variables that are themselves correlated with measures of religiosity. These results are provisional and subject to revision and correction as the outbreak continues to run its course; however, they do suggest that a closer examination of the effect of religion and spirituality - not only on disease spread, but on psychological and social adaptation and resilience in the face of this crisis - merit further investigation, preferably from a transcultural perspective.

\section{Declarations}

Acknowledgements: The author wishes to thank all researchers and publishers who have made COVID-19 research easily accessible.

Conflict of interest: The author reports no current or potential conflict of interest with reference to the work presented in this paper.

Funding source: No funding was received for the work presented in this paper.

\section{References}

Al-Tawfiq, J.A., Leonardi, R., Fasoli, G., \& Rigamonti, D. (2020). Prevalence and fatality rates of COVID-19: what are the reasons for the wide variations worldwide? Travel Medicine and Infectious Disease, Apr 29, 101711. https://doi.org/10.1016/j.tmaid.2020.101711

Archambeau, N. (2011). Healing options during the plague: survivor stories from a fourteenth-century canonization inquest. Bulletin of the History of Medicine, 85, 531-559. 
Asmundson, G.J.G., \& Taylor, S. (2020). Coronaphobia: fear and the 2019-nCoV outbreak. Journal of Anxiety Disorders, 70, 102196. https://doi.org/10.1016/j.janxdis.2020.102196

Bonelli, R.M., \& Koenig, H.G. (2013). Mental disorders, religion and spirituality 1990 to 2010: a systematic evidence-based review. Journal of Religion and Health, 52, 657-673. https://doi.org/10.1007/s10943-0139691-4

Chiriboga, D., Garay, J., Buss, P., Madrigal, R.S., Rispel, L.C. (2020). Health inequity during the COVID-19 pandemic: a cry for ethical global leadership. The Lancet, May 15. https://doi.org/10.1016/S01406736(20)33145-4

Cohen, A., Wu, M.S., \& Miller, J. (2016). Religion and culture: individualism and collectivism in the East and West. Journal of Cross-Cultural Psychology, 47, 1236-1249.

https://doi.org/10.1177/00220022116667895

Du, R.H., Liang, L.R., Yang, C.Q., Wang, W., Cao, T.Z., Li, M., Guo, G.Y., Du, J., Zheng, C.L., Zhu, Q., Hu, M., Li, X.Y., Peng, P., \& Shi, H.Z. (2020). Predictors of mortality for patients with COVID-19 pneumonia caused by SARS-CoV-2: a prospective cohort study. European Respiratory Journal, 55, 2000524.

https://doi.org/10.1183/13993003.00524-2020

Koenig, H.G. (2012). Religion, spirituality, and health: the research and clinical implications. ISRN Psychiatry, 2012, 278730. https://doi.org/10.5402/2012/278730

Koenig, H.G. (2020). Maintaining health and well-being by putting faith into action during the COVID-19 pandemic. Journal of Religion and Health, May 14, 1-10. https://doi.org/10.1007/s10943-020-01035-2

Norenzayan, A., \& Shariff, A.F. (2008). The origin and evolution of religious prosociality. Science, 322, 5862. https://doi.org/10.1126/science.1158757

Pew Research Center. (2018). The age gap in religion around the world. Pew Research Center, June 13.

Pfefferbaum, B., \& North, C.S. (2020). Mental health and the COVID-19 pandemic. The New England Journal of Medicine, Apr 13, 1-3. https://doi.org/10.1056/NEJMp2008017

Quadri, S.A. (2020). COVID-19 and religious congregations: implications for spread of novel pathogens. International Journal of Infectious Diseases, May 3, 1-10. https://doi.org/10.1016/j.ijid.2020.05.007

Rajkumar, R.P. (2020). COVID-19 and mental health: a review of the existing literature. Asian Journal of Psychiatry, 52, 102066. https://doi.org/10.1016/j.ajp.2020.102066

Roberts, L., Ahmed, I., \& Davison, A. (2009). Intercessory prayer for the alleviation of ill health. Cochrane Database of Systematic Reviews, 2, CD000368. https://doi.org/10.1002/14651858.CD000368.pub3 
Schupbach, W.M. (1976). A Venetian "plague miracle" in 1464 and 1576. Medical History, 20, 312-316. https://doi.org/10.1017/s0025727300022699

United Nations Development Programme. (2019). Human development report 2019. Beyond income, beyond averages, beyond today: inequalities in human development in the $21^{\text {st }}$ century. New York, United Nations Development Programme.

Van Ness, P.H., \& Larson, D.B. (2002). Religion, senescence and mental health: the end of life is not the end of hope. American Journal of Geriatric Psychiatry, 10, 386-397. 